practice

\author{
Reducing the diagnostic odyssey \\ OPEN
}

Nicholas E. Johnson, MD

Deputy Editor

Correspondence to

Dr. Johnson:

nicholas.johnson@hsc.utah.edu

Neurol Genet

2015;1:e37; doi: 10.1212/

NXG.0000000000000037
The current issue of Neurology ${ }^{\circledR}$ Genetics emphasizes the unparalleled role of next-generation sequencing (NGS) in defining an expanding spectrum of genetic neurologic disorders. Clinically, NGS encompasses the use of large gene panels, whole-exome sequencing (WES), or whole-genome sequencing (WGS). The impact of NGS technology is twofold. First, researchers have discovered novel genes as the cause of neurologic disorders. This research includes the efforts of Martikainen et al. ${ }^{1}$ to define further the phenotype of a previously reported $S N C A$ mutation that is associated with autosomal dominant Parkinson disease. Second and more common is the connection of novel phenotypes with previously described genes. Several articles in the current issue highlight the role of NGS in this effort. For example, Schottman et al. ${ }^{2}$ identified REEP1 mutations as the cause of a severe axonal neuropathy with a spinal muscular atrophy with respiratory distress (SMARD) phenotype. This gene was previously associated with a hereditary spastic paraplegia phenotype. Similarly, Shieh et al. ${ }^{3}$ expand the phenotype associated with mutations in L1CAM to a neuronal migration phenotype.

When evaluating the impact of NGS, it is clear that previously described genetic disorders include a wider spectrum of phenotypes than previously appreciated. This makes it challenging for the practicing clinician to see a patient, identify a candidate mutation, and test for a single genetic disorder with relative efficiency. Sequential gene testing or Sanger-based genetic panels are time-consuming for both the practitioner and the patient and may lead to a prolonged diagnostic odyssey at great expense. The estimated cost for full-panel testing for Charcot-Marie-Tooth disease ranges from $\$ 1,500$ to $\$ 7,000$, compared to the cost of CLIAconforming WES at $\$ 4,500$. Clearly, NGS technology has the potential to cast a wide net and may arrive at a conclusive diagnosis with relative efficiency. However, as Dr. Angelini ${ }^{4}$ notes, cost is still a factor in the use of this technology.

Given the increasing availability of NGS testing as highlighted by this issue of Neurology: Genetics, we would like to review some best practices for ordering NGS. For a complete review, please see the American College of Medical Genetics and Genomics policy statement on this issue. ${ }^{5}$

The first issue to consider concerns the selection of patients who are the best candidates for testing using NGS techniques. A single genetic test may still be best to assess classic genotype-phenotype correlations. A patient with grip myotonia and early-onset cataracts would require a genetic test only for myotonic dystrophy type 1 . The currently available NGS technology may not be able to detect individuals suspected of having a repeat expansion disorder (e.g., spinocerebellar ataxia) or a mutation in a noncoding region (e.g., facioscapulohumeral muscular dystrophy).

WES may better assess phenotypes with broad phenotypic variability and overlap of many potential genetic causes. Several reports in the current issue provide evidence of this and start with a population-based cohort. In these articles, the yield for NGS was 5.6\%$59 \%$, which is similar to previous reports of a $32.1 \%$ positive diagnostic rate with NGS. ${ }^{6-8}$ Some of this variation in the diagnostic sensitivity of NGS is the result of how selective the cohort was relative to the phenotype.

In the United States, insurance approval may be an issue, although we would argue that the positive yield for appropriately selected cases is higher than that of other commonly approved tests (e.g., chromosomal microarray). ${ }^{9}$ Overall, for individuals suspected of having a genetic disorder, NGS may provide a costeffective diagnostic tool and should not be reserved as a "last resort."

The process of identifying variants and accepting them as pathogenic is a second practice worth noting. The increasing use of sequencing technology in a larger population of individuals has identified increasing variation in the genome. Should a clinician order NGS (especially WES or WGS) for a patient, there is a high likelihood that a list of "variants of uncertain significance" will be issued. Many of these variants will prove benign, and most

From the Department of Neurology, University of Utah, Salt Lake City.

Funding information and disclosures are provided at the end of the editorial. Go to Neurology.org/ng for full disclosure forms.

This is an open access article distributed under the terms of the Creative Commons Attribution-NonCommercial-NoDerivatives License 4.0 (CC BYNC-ND), which permits downloading and sharing the work provided it is properly cited. The work cannot be changed in any way or used commercially. 
laboratories doing NGS testing will provide an assessment of the pathogenicity of the variant, but it should be considered with caution. Currently available informatics tools to assess pathogenicity require significant expertise. Any rare variant has the potential to be pathogenic even if bioinformatics tools predict that the variant is benign. Similarly, variants with predicted pathogenicity are commonly proved benign in later studies. Much like any other type of referral, the discovery of a rare variant in a patient thought to be pathogenic may prompt a referral to a colleague with specialized interpretation in this area. Indeed, both Nascimento et al. ${ }^{10}$ and Sullivan et al. ${ }^{11}$ report novel mutations in previously associated genes. Whenever possible, sequencing of both parents and the proband will substantially increase the interpretability of any variants detected. Of course, clinicians also need to prepare for unexpected results. For example, test results may identify BRCA1 mutations in a patient with a hereditary neuropathy. Often, a genetic counselor can be invaluable for navigating the results.

As the current issue of Neurology: Genetics shows us, NGS technology has had a profound impact on how we practice neurology. The expanding phenotypes of these genetic disorders have blurred classically defined genotype-phenotype correlations, sometimes making it difficult for both clinicians and patients to know how to proceed with genetic testing. We hope that the best practices delineated here will provide some guidance to the practicing neurologist and offer this revolutionary tool to all patients who need it.

\section{STUDY FUNDING}

No targeted funding reported.

\section{DISCLOSURE}

N. Johnson serves as Deputy Editor of Neurology: Genetics and has received research support from ISIS Pharmaceuticals, Biogen Idec, Valerion Therapeutics, and the Muscular Dystrophy Association. Go to Neurology.org/ng for full disclosure forms.

\section{REFERENCES}

1. Martikainen MH, Paivarinta M, Hietala M, Kaasinen V. Clinical and imaging findings in Parkinson disease associated with the A53E SNCA mutation. Neurol Genet 2015; 1:e27. doi: 10.1212/NXG.0000000000000027.

2. Schottmann G, Seelow D, Seifert F, et al. Recessive REEP1 mutation is associated with congenital axonal neuropathy and diaphragmatic palsy. Neurol Genet 2015;1:e32. doi: 10.1212/NXG.0000000000000032.

3. Shieh C, Moser F, Graham JM Jr, Watiker V, Pierson TM. Mutation in the sixth immunoglobulin domain of L1CAM is associated with migrational brain anomalies. Neurol Genet 2015;1:e34. doi: 10.1212/ NXG.0000000000000034.

4. Angelini CI. An LGMD phenotype due to a new gene and dysferlinopathy investigated by next-generation sequencing. Neurol Genet 2015;1:e39. doi: 10.1212/ NXG.0000000000000039.

5. American College of Medical Genetics and Genomics (ACMG). Policy Statement: Points to Consider in the Clinical Application of Genomic Sequencing. Available at: http:// www.acmg.net/StaticContent/PPG/Clinical_Application_ of_Genomic_Sequencing.pdf. Accessed October 26, 2015.

6. Izumi R, Niihori T, Takahashi T, et al. Genetic profile for suspected dysferlinopathty identified by targeted nextgeneration sequencing. Neurol Genet 2015;1:e36. doi: 10. 1212/NXG.0000000000000036.

7. Boillot M, Morin-Brureau M, Picard F, et al. Novel GABRG2 mutations cause familial febrile seizures. Neurol Genet 2015;1:e35. doi: 10.1212/NXG.0000000000000035.

8. Iglesias A, Anyane-Yeboa K, Wynn J, et al. The usefulness of whole-exome sequencing in routine clinical practice. Genet Med 2014;16:922-931.

9. Michelson DJ, Shevell MI, Sherr EH, Moeschler JB, Gropman AL, Ashwal S. Evidence report: Genetic and metabolic testing on children with global developmental delay: report of the Quality Standards Subcommittee of the American Academy of Neurology and the Practice Committee of the Child Neurology Society. Neurology 2011;77:1629-1635.

10. Nascimento FA, Borlot F, Cossette P, Minassian BA, Andrade DM. Two definite cases of sudden unexpected death in epilepsy in a family with a DEPDC5 mutation. Neurol Genet 2015;1:e28. doi: 10.1212/NXG.0000000000000028.

11. Sullivan JM, Zimanyi CM, Aisenberg W, et al. Novel mutations highlight the key role of the ankyrin repeat domain in TRPV4-mediated neuropathy. Neurol Genet 2015;1:e29. doi: 10.1212/NXG.0000000000000029. 


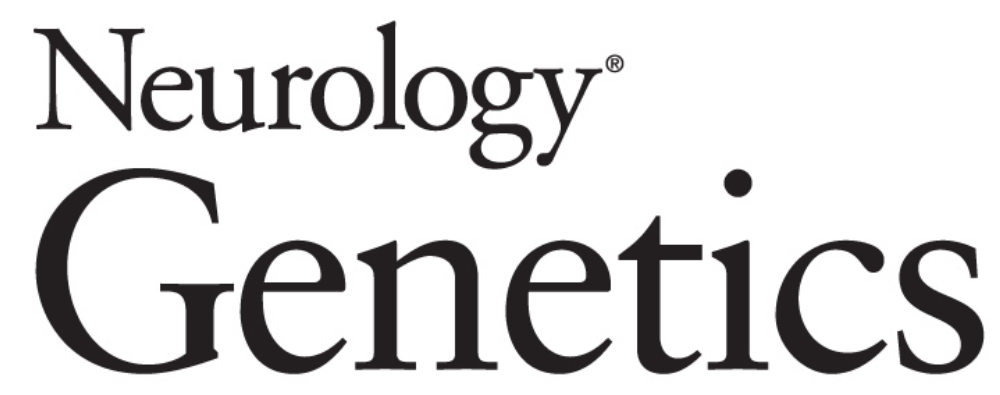

Whole-exome sequencing in neurologic practice: Reducing the diagnostic odyssey Nicholas E. Johnson

Neurol Genet 2015;1;

DOI 10.1212/NXG.0000000000000037

This information is current as of December 24, 2015

$\begin{array}{ll}\begin{array}{l}\text { Updated Information \& } \\ \text { Services }\end{array} & \begin{array}{l}\text { including high resolution figures, can be found at: } \\ \text { http://ng.neurology.org/content/1/4/e37.full.html }\end{array} \\ \text { References } & \begin{array}{l}\text { This article cites } 10 \text { articles, } 8 \text { of which you can access for } \\ \text { http://ng.neurology.org/content/1/4/e37.full.html\#\#ref-lis }\end{array} \\ \text { Permissions \& Licensing } & \begin{array}{l}\text { Information about reproducing this article in parts (figure } \\ \text { its entirety can be found online at: } \\ \text { http://ng.neurology.org/misc/about.xhtml\#permissions }\end{array} \\ \text { Reprints } & \begin{array}{l}\text { Information about ordering reprints can be found online: } \\ \text { http://ng.neurology.org/misc/addir.xhtml\#reprintsus }\end{array}\end{array}$

Updated Information \&

References

(n)

Neurol Genet is an official journal of the American Academy of Neurology. Published since April 2015, it is an open-access, online-only, continuous publication journal. Copyright (C) 2015 American Academy of Neurology. All rights reserved. Online ISSN: 2376-7839.

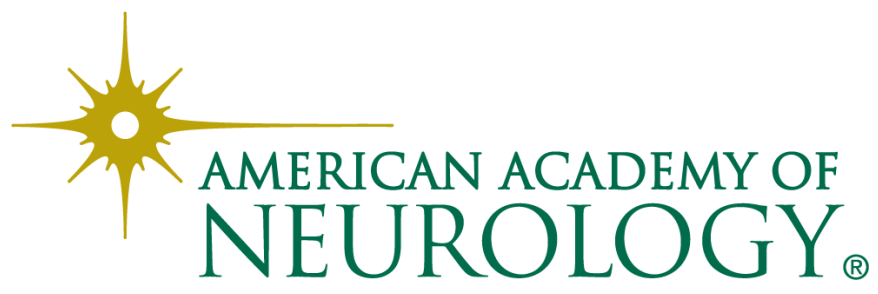

